\title{
KURIOS
}

(Jurnal Teologi dan Pendidikan Agama Kristen)

Vol. 1, No. 1, Oktober 2013 (22-34)

ISSN 2406-8306 (print)

http://www.sttpb.ac.id/e-journal/index.php/kurios

\section{Falsafah "Nrimo" Dalam Budaya Jawa Ditinjau Dari Tugas Pendidikan Kristen Berdasarkan Perspektif Psikologis}

\author{
Yeni Krismawati \\ Sekolah Tinggi Teologi Pelita Bangsa Jakarta
}

\section{Pendahuluan}

Falsafah "nrimo" (menerima) sudah berurat akar dalam kehidupan orang Jawa pada umumnya. W.J.S. Poerwadarminta mendefinisikan "nrimo" adalah menerima apa adanya (Kamus Umum Bahasa Indonesia, 1976:678). Lebih jauh M.S. Sastrosupono menjelaskan bahwa nrimo merupakan salah satu nilai budaya Jawa yang tidak dapat dipisahkan dari unsur kesabaran dan kerelaan (Sinkretisme dan Orang Kristen Jawa, 1984:15). Adapaun definisi nrimo atau menerima yang diberikan Niels Mulder erat kaitannya dengan sikap menerima kehidupan sebagaimana adanya sambil menumbuhkan kedamaian jiwa dan ketenangan emosi. "Nrimo berarti percaya pada nasib sendiri dan berterima kasih kepada "Tuhan" karena ada kepuasan dalam memenuhi apa yang menjadi bagiannya dengan kesadaran bahwa semuanya telah ditetapkan" (Pribadi dan Masyarakat di Jawa, 1996:25).

Melihat kembali arti falsafah nrimo dalam konteks budaya Jawa, nilai-nilai luhur tersebut patut dijaga bahkan diteladani. Namun demikian muncul pro-kontra apakah sebagai orang Jawa yang telah menjadi Kristen falsafah ini dapat dibenarkan mengingat terjadi distorsi dari definisi nrimo sebagai sikap penerimaan yang terpaksa. Sejauh manakah unsur dalam falsafah nrimo dapat diterapkan atau ditolak berkaitan dengan kehidupan iman Kristen?

Berikut beberapa kasus yang dipaparkan berkaitan dengan kuatnya pengaruh fasafah nrimo dalam kehidupan masyarakat Jawa. Mengingat luasnya ruang lingkup masyarakat Jawa serta tujuan penulisan makalah berkaitan dengan peran pendidikan Kristen, maka pengamatan dibatasi pada komunitas Jawa yang telah menjadi Kristen. 
Salah satu lembaga pendidikan Kristen di Yogyakarta mempunyai pemimpin yang dikenal otoriter. Berbagai kebijaksanaan yang ditentukannya tanpa melibatkan orang lain serta cenderung mencari nama bagi diri sendiri. Mulai tahun 1997 hingga tahun ini, satu-persatu staf dari berbagai suku menyatakan diri untuk mundur dari lembaga tersebut karena tidak setuju dengan sistem yang berlaku. Dalam pengamatan terhadap kasus ini, para staf yang masih bertahan kebanyakan adalah orang Jawa. Memang ada suku lain yang tetap mengajar pada lembaga tersebut, tetapi karakternya tidak jauh berbeda dengan orang Jawa pada umumnya yang lebih memilih untuk nrimo daripada konfrontasi yang mendatangkan resiko. Pada akhirnya posisi bagus dapat dinikmati oleh para staf yang bertahan tetapi ada kesan bahwa mereka menjadi semacam "pemimpin boneka" yang dikendalikan oleh bos otoriter (sumber: dituturkan oleh salah satu alumni mahasiswa universitas tersebut, yang sekarang menjadi dosen di Jakarta).

Kasus lain terjadi pada tahun 1998 sampai dengan pertengahan 2000, terjadi pada salah satu Institusi Pendidikan Kristen di Jawa Barat dengan mahasiswa yang terdiri dari beragam suku. Kasus yang berkaitan dengan sikap nrimo dialami oleh dua orang pengurus harian SEMA (Senat Mahasiswa) institusi tersebut. Selama periode mereka menjalankan tugas, setiap kali diadakan kegiatan SEMA yang membutuhkan tenaga seperti membuat dekorasi, menyediakan berbagai perlengkapan maupun pemerhati kebersihan, dari antara pengurus harian, yang terlihat setia bekerja adalah mereka berdua. Menurut kedua mahasiswa yang adalah suku Jawa tersebut, kerjasama untuk melakukan tugas sudah disepakati untuk dilakukan bersama. Tetapi kenyataannya semua pengurus yang berasal dari suku lain tidak konsisten dengan kesepakatan bersama meskipun sudah diingatkan. Kedua mahasiswa tersebut berpendapat siapa lagi yang mau bekerja kalau saling mengandalkan satu dengan yang lain. Dalam hal ini nrimo menurut mereka adalah sikap yang tepat sebagai bukti kerendahan hati seseorang untuk memberikan contoh kepada teman yang lain (narasumber adalah kedua mahasiswa yang menjadi obyek kasus).

Kasus berikut dialami oleh anak dari keluarga Jawa yang dilukai oleh temannya padahal ia tidak bersalah. Sang anak ngotot ingin mengadukan masalah tersebut kepada orangtua dari teman yang melukainya. Tetapi ibunya melarang dan menjelaskan bahwa sikap seperti itu tidak sopan. Lebih baik diam saja dan tidak usah lagi bermain dengan teman yang nakal tadi. Dalam hal ini sang ibu masih memegang prinsip “wani ngalah 
luhur wekasane" yang artinya siapa berani mengalah pada akhirnya akan menerima kehormatan (Kasus diangkat dari pengalaman keluarga dalam pelayanan).

Beberapa permasalahan perlu dibahas mengingat falsafah nrimo telah menjadi budaya yang mempengaruhi perkembangan pribadi orang Jawa pada umumnya. Nilai tersebut besar pengaruhnya bagi orang Jawa sekalipun telah menjadi percaya, dengan demikian peran pendidikan Kristen untuk mengarahkan penerapan falsafah tersebut sangat penting. Untuk lebih mengarahkan penulisan makalah ini, maka diajukan beberapa pertanyaan penuntun sebagai berikut: Mengapa nrimo menjadi falsafah hidup orang Jawa? Sejauhmana nilai-nilai falsafah nrimo mempengaruhi masyarakat Jawa?

Bagaimanakah Peran Pendidikan Kristen dalam membina orang Jawa yang telah menjadi percaya, menyikapi falsafah tersebut?

\section{Tinjauan Historis Sosiologis Terhadap Falsafah Jawa}

Untuk melihat lebih jelas terbentuknya falsafah nrimo, perlu ditelusuri pengaruh sejarah serta dampaknya bagi hubungan antar pribadi dalam masyarakat Jawa maupun pihak luar. Penelitian sejarah dimulai pada masa kebudayaan Hindu dan Budha dengan berdirinya berbagai kerajaan sampai dengan masa penjajahan yang cukup lama menguasai Indonesia khususnya pulau Jawa.

\section{Nilai-nilai Hidup Kerajaan}

Kejayaan suku Jawa pada masa lampau cukup dikenal melalui bentuk pemerintahan kerajaan dimulai pada masa kebudayaan Hindu-Budha sampai dengan masuknya kekristenan ke Indonesia (Sejarah Nasional dan Sejarah Umum, 1997:73). Kemasyuran kerajaan-kerajaan Jawa tidak hanya dikenal diwilayah kepulauan Nusantara, melainkan sampai kepada bangsa-bangsa asing. Kejayaan Majapahit dibawah Raden Wijaya pada tahun 1293-1309 dilanjutkan Patih Majapahit, kejayaan Singosari di Malang, kemasyuran Blambangan di Banyuwangi, Demak, kraton Jogjakarta dan Surakarta yang kesemuanya membawa pangaruh bagi perkembangan masyarakat Jawa. Salah satu budaya kerajaan yang dianut bahkan menjadi bagian hidup orang Jawa ialah jiwa kehambaan sebagai abdi raja atau penguasa. Sebagai rakyat yang mengabdi pada negara, orang Jawa memegang prinsip untuk selalu taat melakukan perintah atasan. Rakyat menjadi hamba yang harus patuh kepada penguasa. Berdasarkan wawancara dengan "abdi dalem kaputren" (pelayan permaisuri dan putri raja), para prajurit serta guide Kerajaan Jogjakarta, pada umumnya mereka adalah pengabdi setia kerajaan sejak 
kecil. Dilihat dari tunjangan hidup, mereka hanya menerima gaji minim. Tetapi hal tersebut tidak menjadi masalah karena bagi mereka, dipercayakan sebagai abdi dalem atau bagian dari kerajaan merupakan kebanggaan tersendiri.

Pandangan inilah yang menjadi salah satu faktor mengapa orang Jawa memiliki kecenderungan untuk selalu menerima apa saja yang diperlakukan orang lain. Sikap tersebut dianggap positif untuk menunjukkan rasa hormat dan patuh kepada atasan.

\section{Mentalitas "Rodi" dan "Romusa" Masa Penjajahan}

Tak dapat dipungkiri bahwa salah satu faktor berkembangnya falsafah nrimo ialah pengaruh dari kehadiran penjajah yang cukup lama berkuasa di Indonesia. Pulau Jawa sebagai pusat kejayaan kerajaan pada masa lampau, menjadi wilayah operasional bagi para penjajah. Selama kurun waktu tiga ratus lima puluh tahun pemerintahan Belanda ditambah tiga setengah tahun penjajahan Jepang, rakyat di pulau Jawa lebih banyak mengalami penderitaan. Penerapan sistem rodi masa pemerintahan Belanda serta romusa yang diterapkan Jepang merupakan kerja paksa yang mengakibatkan terbentuknya mental budak dalam masyarakat Jawa.

Kelompok AGGRA Institute berpendapat bahwa mental budak semakin berkembang di kalangan rakyat kelas rendah karena mereka menjadi pengerja di perkebunan-perkebunan dengan pemerasan tenaga yang luar biasa (Hangudi Luhuring Budaya Jawa, 2002:60). Kekejaman penjajah tidak memberikan pilihan kepada masyarakat Jawa kecuali mengikuti seluruh aturan dan menjalankannya meskipun sangat berat.

\section{Pemeliharaan Relasi Antar Sesama}

Mancanegara mengenal suku Jawa sebagai masyarakat yang ramah, lemah lembut dan menghargai orang lain. Sikap tersebut berdasarkan adat istiadat yang menunjukkan tata krama luhur. M.S. Sastrosupono menekankan bahwa salah satu bentuk pelaksanaan tata krama ialah menerima orang lain, budaya dan agama atau keyakinan sekalipun banyak hal yang bertentangan (Sinkretisme dan Orang Kristen Jawa, 1984:6). Sikap tidak sampai hati untuk menolak karena dapat menimbulkan pertentangan menunjukkan tingginya etika yang penting untuk dipertahankan. Dengan demikian sikap nrimo lebih menjadi sebuah pilihan untuk menjaga relasi agar tetap harmonis meskipun ditemukan nilai-nilai yang bertentangan baik secara pribadi maupun bermasyarakat. 


\section{Tinjauan Psikologis}

Berbagai segi yang mempengaruhi perkembangan psikologis seseorang ditentukan oleh faktor endogen dan eksogen (Psikologi Perkembangan Anak dan Remaja, 1989:127). Demikian juga dengan falsafah nrimo yang melekat dalam masyarakat Jawa merupakan produksi dari faktor eksogen. Falsafah nrimo ditanamkan, dicontohkan serta didemonstrasikan oleh orangtua sehingga anak menjadi terbiasa dengan pola tersebut. Karena sejak kecil anak secara berkesinambungan terhisap dalam budaya nrimo masyarakat, maka terbentuklah pribadi dewasa yang telah sedemikian rupa dipengaruhi oleh falsafah tersebut.

Berbagai teori perkembangan psikologi dapat dipakai untuk melihat sejauhmana pengaruh budaya nrimo dalam kehidupan manusia yang dilahirkan maupun dibesarkan di kalangan masyarakat Jawa. Teori-teori tersebut membantu para pendidik Kristen menemukan nilai yang penting untuk dikembangkan atau dicegah demi terbentuknya pribadi yang sehat dengan berpedoman kepada firman Tuhan.

\section{Falsafah Nrimo Dalam Pandangan Psikososial}

Mengkaji falsafah nrimo berdasarkan teori E. Erikson cukup menarik mengingat sudut pandang yang dipakai sebagai tolok ukur perkembangan seseorang ialah interaksi gejala psikis, edukatif serta sosial (Psikologi Perkembangan, 2002:14). Sejalan dengan pemikiran Albert Bandura melalui teori belajar sosialnya menjelaskan bahwa perkembangan merupakan proses belajar sosial yang terus-menerus. Dalam hal ini lingkungan memegang peranan besar dalam perkembangan kepribadian sehingga muncullah perilaku yang baru (Psikologi Perkembangan Anak dan Remaja, 1989:206). Anak yang secara berulang-ulang melihat contoh dan menerima falsafah nrimo pada akhirnya akan memiliki perilaku yang sejalan dengan nilai tersebut.

Berdasarkan tahapan perkembangan manusia yang dibuat Erikson, falsafah nrimo dapat berfungsi sebagai pendorong sekaligus penghambat. Berikut beberapa tahapan yang berkaitan langsung dengan pembentukan falsafah nrimo:

\section{Terhambatnya Inisiatif}

Dalam falsafah nrimo, inisiatif yang seharusnya perlu dikembangkan demi mendorong kemandirian anak justru dihambat. Pada masa ini Erikson berpandangan bahwa seharusnya anak belajar menjadi dewasa melalui inisiatif dengan mencoba menerima tanggung jawab yang masih berada di luar kemampuannya melalui pengujian 
diri (Nurture That Is Christian, 1995:97). Sebaliknya unsur yang terkandung dalam falsafah nrimo cenderung kurang memberi kesempatan kepada anak untuk mengembangkan inisiatif. Anak diajar untuk menerima segala sesuatu atas kendali orangtua dan masyarakat. Akibatnya ialah anak menjadi pasif, tidak berani mencoba sesuatu karena takut apa yang dilakukannya salah, dengan demikian menunggu instruksi merupakan pilihan terbaik.

\section{Falsafah Nrimo Bagi Terbentuknya Kompetensi}

Keutamaan dasar yang dibutuhkan anak pada usia ini ialah kompetensi. Newman \& Newman menjelaskan bahwa salah satu ciri yang dimiliki anak usia 6-12 tahun ialah masa produktif dan aktif dimana anak ingin terhindar dari inferioritas (Pendewasaan Manusia Dewasa, 2003:15). Dalam falsafah nrimo, kebutuhan untuk berkompetensi terhambat karena nilai yang ditanamkan orangtua maupun masyarakat mengakibatkan anak mudah menyerah dengan keadaan. Begitu juga keberanian menghadapi tantangan tidak berkembang sehingga anak bertumbuh sebagai pribadi yang cenderung menghindari masalah. Pengaruh nilai tersebut terlihat dari kenyataan bahwa dalam instansi pemerintah atau lembaga lain, orang Jawa lebih berada sebagai pihak yang dipimpin daripada sebagai pemimpin.

\section{Nrimo Untuk Memelihara Keakraban}

Salah satu nilai yang terkandung dalam falsafah nrimo ialah rela menerima perlakuan yang merugikan sekalipun demi memelihara relasi dengan orang lain atau kelompok. Nilai tersebut sejalan dengan penelitian M. Suprihadi Sastrosupono yang menjelaskan bahwa orang Jawa memiliki tepa seliro atau sikap tenggang rasa yang baik. "Seringkali orang Jawa mengorbankan kepentingan pribadi, demi mempertahankan persahabatan dan pergaulan dengan orang lain (Sinkretisme dan Orang Kristen Jawa, 1984:5).

Dikaitkan dengan teori Erikson, usia 20-40 tahun mengalami krisis keakraban vs keterasingan, itu sebabnya tugas utama pada masa ini ialah membangun suatu bentuk persahabatan dan belajar mencapai rasa cinta dan kebersamaan (Nurture That Is Christian, 1984:98). Falsafah nrimo merupakan salah satu sarana menumbuhkan kebutuhan untuk menghargai, mempercayai, memperhatikan dan sebaliknya, demi terciptanya kebersamaan. Itu sebabnya banyak orang Jawa berhasil menjalankan 
fungsinya sebagai penengah dalam suatu konflik karena falsafah nrimo memupuk sifat diplomatis.

\section{Falsafah Nrimo Ditinjau Dari Perkembangan Moral}

Tinjauan psikologis terhadap falsafah nrimo tidak bisa dilepaskan dari perkembangan moral. Kohlberg berpendapat, prinsip moral bukannya apa yang baik atau buruk melainkan bagaimana seseorang sampai kepada keputusan bahwa sesuatu itu baik dan buruk (Teaching for Spiritual Growth, 1994:100). Tiga tingkatan teori Kohlberg, yaitu:

Pra-Konvensional (4-10 tahun), suatu masa dimana anak berorientasi pada hukuman, kepatuhan dan ketaatan. Konvensional (10-13 tahun), yang artinya dalam tahap ini anak berorientasi pada penyesuaian antar pribadi terhadap hukuman, tata tertib dan aturan. Post-Konvensional (13 tahun + ), dimana anak mempunyai prinsip nurani bahwa tindakan benar difahami dari segi hak-hak individual yang umum dan aturan yang sudah disetujui oleh masyarakat (Christian Education, 2001:75).

Karena teori Kohlberg merupakan hasil pengembangan dari teori Piaget, maka perkembangan moral erat kaitannya dengan perkembangan kognitif. Apa yang disampaikan Selman dan Byrne dengan perkembangan sikap ambil alih peran, juga mempengaruhi perkembangan moral seseorang (Psikologi Perkembangan, 2002:315).

\section{Nrimo Yang Dipaksakan}

Pada tahap pra-konvensional dan konvensional, orangtua menanamkan falsafah nrimo baik melalui contoh maupun perlakuan kepada anak dengan lebih mudah. Disamping anak masih berorientasi untuk menghindari hukuman dan memperoleh hadiah, perkembangan sosial-kognitif anak masih bersifat egosentris dimana tingkat berpikir anak untuk menerima begitu saja falsafah nrimo sebagai pilihan tidak begitu membutuhkan pertimbangan. Melalui falsafah tersebut, anak belajar mengembangkan beberapa sikap positif seperti rendah hati, menghargai orang lain, taat kepada otoritas orangtua atau guru, memelihara kerukunan serta melatih kesopanan anak.

Tetapi yang perlu diwaspadai oleh orangtua ialah nilai nrimo yang dipaksakan mengakibatkan beberapa hal: Anak dapat bertumbuh menjadi penakut karena penerimaan terhadap sesuatu dengan terpaksa untuk menghindari hukuman, munafik karena terlalu menjaga sikap di hadapan orang lain atau masyarakat meskipun tidak setuju dengan prinsip yang berlaku, mengorbankan nilai kebenaran untuk menghindari 
konfrontasi (misalnya, membenarkan perbuatan teman karena takut dimusuhi atau diancam).

\section{Nrimo Yang Sesungguhnya}

Unsur nrimo dapat diterima dengan sesungguhnya pada tahap postkonvensional. Anak yang memasuki masa remaja meskipun masih mau diatur secara ketat oleh hukum-hukum umum tetapi tingkah laku moralnya mulai diputuskan berdasarkan tanggung jawab hati nuraninya (Psikologi Perkembangan, 2002:313). Apabila orangtua bersikap tidak adil dalam memperlakukan anak-anaknya, remaja mulai menunjukkan ketidaksetujuannya melalui penolakan halus atau protes secara terang-terangan yang biasanya diwujudkan dalam bentuk pemberontakan. Menjadi sesuatu yang agak sulit bagi remaja untuk menerima begitu saja reaksi-reaksi lingkungan yang tidak sesuai dengan kemauan mereka. Sebaliknya berbagai aturan yang mereka anggap baik atau menyenangkan dapat diterima dengan sikap nrimo.

Namun tidak selamanya usia remaja dapat menjadi tolok ukur bagi penerimaan falsafah nrimo dalam arti yang sesungguhnya. Selain faktor usia, pertimbangan moral juga dipengaruhi oleh pengalaman (role talking), masa studi, intelegensi, pola asuh, dan jenis kelamin (Psikologi Perkembangan Perspektif Sepanjang Hayat, 1992:80). Dengan demikian orang dewasa yang minim dengan faktor-faktor di atas, akan tetap pada tahap nrimo yang dipaksakan.

\section{Motivasi Pembiasaan Demokrasi}

Salah satu kelemahan falsafah nrimo ialah memudarkan kemampuan anak untuk memutuskan sesuatu berdasarkan pilihan pendapatnya sendiri. Reaksi orangtua ialah melarang atau marah ketika anak mengutarakan pilihannya. Sebaliknya anak diperintahkan untuk tidak banyak bicara kecuali menerima penuh keputusan orangtua tanpa adanya pilihan lain. Sylvia Rimm berpendapat bahwa memberikan pilihan kepada anak dalam pengambilan keputusan merupakan latihan intelektual yang baik sehingga kelak anak sudah terlatih mengambil pilihan yang tepat dalam hidupnya (Mendidik dan Menerapkan Disiplin pada Anak Prasekolah, 2003:5).

\section{Tugas Pendidikan Kristen Sebagai Solusi Menyikapi Falsafah Nrimo}

Mengingat tidak sepenuhnya nilai dalam falsafah nrimo berdampak negatif bagi perkembangan hidup seseorang, Pendidikan Kristen berperan menggali nilai positif yang berguna bagi perkembangan masyarakat Jawa. Ada banyak hal yang dapat 
dilakukan untuk mencegah serta menanggulangi pengaruh falsafah nrimo. S. Wismoady Wahono menjelaskan kematangan dan kedewasaan seseorang berkaitan erat dengan kehidupan keagamaan serta kebudayaan baik secara individu maupun kolektif (ProEksistensi, 2001:48). Kejelian untuk menyikapi setiap kebudayaan berdasarkan terang Firman Tuhan, mampu menjadikan kebudayaan dengan segala dinamikanya, demi terbentuknya pribadi yang berkarakter sehat.

\section{Nilai-nilai Positif yang Dapat Dikembangkan}

Sejauhmana setiap kebudayaan dapat diterapkan atau sebaliknya ditolak, ditinjau dari sudut kekritenan? Alkitab menjadi dasar yang berfungsi sebagai barometer kebenaran. Beberapa batasan yang disampaikan Y. Tomatala terhadap kontekstualisasi iman Kristen dengan budaya antara lain:

Berpegang kepada prinsip bahwa Alkitab adalah firman Allah; Allah sebagai pencipta abadi; Hanya Tuhan Yesus satu-satunya Juruselamat; Roh Kudus adalah Allah, Penolong, Pembimbing dan Pemberi hidup yang berkemenangan; Manusia adalah berdosa dan hanya diselamatkan oleh karya Kristus; Gereja adalah umat Allah yang dipanggil sebagai saksi Kristus; Injil harus beradaptasi dengan budaya untuk mengadakan transformasi (Teologi Kontekstualisasi, 2001:89).

Beberapa nilai positif falsafah nrimo yang mendukung perkembangan individu menuju pribadi yang sehat antara lain:

\section{Berkembangnya Nilai Kerendahan Hati}

Salah satu unsur yang terkandung dalam falsafah nrimo ialah sikap rendah hati. Unsur tersebut ditunjang oleh konsep bahwa ilmu padi yang sangaat dipegang oleh masyarakat Jawa "semakin berisi semakin menunduk". Dengan demikian orang yang mengetahui kebenaran akan memilih untuk nrimo atau mengalah sebagai sikap yang menunjukkan kerendahan hati seseorang. Di samping itu, konsep mengalah berarti awal sebuah kemenangan jadi tidak perlu menuntut, mengeluh atau mempertahankan hak hidup melainkan menerima segala sesuatu "klawan ati legowo" (dengan hati lapang).

Tentu nilai positif ini sejalan dengan firman Tuhan bahwa rendah hati mendahului kehormatan (Ams. 15:33), orang yang rendah hati dikasihi Allah (Yak. 4:6; I Pet. 3:8) dan rendah hati adalah perintah Allah (Ef. 4:2; Kol. 3:12).

\section{Kesabaran}

Salah satu unsur dalam buah Roh yang dikerjakan oleh Roh Kudus bagi orang percaya ialah kesabaran (Gal. 5:22). Pada umumnya suku-suku lain di Indonesia bahkan manca negara mengenal masyarakat Jawa sebagai orang yang sabar. Kesabaran tersebut 
berkembang karena falsafah nrimo yang mengajarkan pentingnya sikap sabar meskipun diperlakukan sewenang-wenang oleh orang lain. Termasuk di dalamnya kesabaran untuk menanggung segala penderitaan hidup. Nilai yang telah melekat ini tentu lebih memudahkan orang Jawa yang menjadi Kristen untuk semakin mengembangkan sikap sabar sesuai dengan ajaran firman Tuhan. Dalam rangka pertumbuhan iman yang berkaitan dengan perjalanan hidup kekristenan, kesabaran sangat penting. Sabar mengalami penderitaan (Rm. 12:12; II Tim. 4:5; Kol. 1:11), sabar dalam hubungan dengan orang lain (Kol. 3:13; I Tes. 5:14), kesabaran sebagai buah iman (I Kor. 13:4; Gal. $5: 22)$.

\section{Penguasaan Diri}

Salah satu unsur dalam falsafah nrimo yang patut dilestarikan ialah kemampuan menguasai diri. Satu diantara 75 Butir-butir Budaya Jawa yang berkaitan dengan hubungan antar manusia ialah "aja panas ten, yang diartikan jangan suka panas hati" (Hangudi Luhuring Budaya Jawa, 2002:54). Butir tersebut menanamkan konsep pentingnya penguasaan diri dalam menjalani kehidupan.

Peran Pendidikan Kristen ialah menanamkan nilai penguasaan diri sebagai "buah Roh” yang penting untuk dinyatakan dalam kehidupan orang percaya (Galatia 5:23). Begitu berartinya nilai penguasaan diri, Alkitab menggambarkan bahwa orang yang mampu menguasai diri melebihi orang yang merebut kota (Amsal 16:32). Sedangkan nasihat rasul Petrus berkaitan dengan kehidupan orang Kristen selama menanti kedatangan Tuhan ialah menguasai diri (I Pet. 4:7). Lebih lanjut dijelaskan bahwa penguasaan diri membawa seseorang menjadi giat dan berhasil dalam pengenalan akan Tuhan Yesus (II Pet. 1:6,8).

\section{Unsur Yang Tidak Perlu Dipertahankan}

Sebagaimana kelebihan masyarakat Jawa dikenal oleh suku atau bangsa lain, maka unsur-unsur dari falsafah nrimo yang tidak baik pun menjadi kendala bagi pertumbuhan iman Kristen.

\section{Kurangnya Keberanian untuk Memihak Kebenaran}

Sikap berani secara tegas pada umumnya tidak banyak dijumpai dalam diri orang Jawa. Mendasari sikap tersebut ialah falsafah nrimo yang tidak mengenal konfrontasi sebagai solusi dalam menghadapi perlakuan orang lain yang tidak benar. Akibat dari sikap tersebut ialah terjadinya kompromi terhadap pelanggaran demi mempertahankan 
apa yang dianggap benar oleh masyarakat. Yang lebih parah lagi berkaitan dengan iman Kristen ialah terjadinya sinkretisme sebagai cara untuk menghargai setiap kepercayaan yang mempengaruhi kehidupan masyarakat.

Alkitab memberikan contoh berkaitan dengan kebenaran yang harus ditegakkan untuk menelanjangi kesewenangan pihak yang hidup tidak benar. Para nabi yang dipercayakan Tuhan untuk menyampaikan firman-Nya memiliki sikap tegas dalam menyatakan kebenaran. Konfrontasi Samuel kepada Saul karena ketidaktaatannya kepada Allah (I Sam. 15:17-23), nabi Mikha terhadap Ahab (I Raja 22:19-23), dan keberanian Elia menyatakan dosa Ahab (I Raja 18:18). Demikian juga dengan Tuhan Yesus yang secara terang-terangan menyatakan kesalahan para pemimpin agama yang justru gagal dalam menjalankan ajaran serta menjadi batu sandungan bagi orang lain (Mat. 23:1-36).

\section{Budaya "Menusuk Dari Belakang"}

Pendidikan Kristen melalui ajarannya perlu mengatasi salah satu unsur falsafah nrimo yang mengkondisikan orang Jawa sulit bersikap transparan baik mengenai dirinya sendiri atau penilaian kepada orang lain. Sikap tersebut terpupuk karena adanya unsur "menerima dengan keterpaksaan". Pendapat atau perlakuan yang sebenarnya tidak disetujui, dengan terpaksa diterima. Sikap tidak setuju atau tidak dapat menerima perlakuan orang lain yang seharusnya dinyatakan lewat ungkapan maupun sikap ssecara jujur, tidak terwujud.

Dampak yang muncul ialah terjadinya pengkhianatan atau perlawanan terselubung sehingga muncullah ungkapan "Menusuk dari Belakang". Sejarah mencatat beberapa pengkhianatan pada masa kerajaan seperti pemberontakan Ranggalawe (1309), Lembu Sora (1311), Ra Tansa (1328) dan masih banyak contoh lain (Sejarah Nasional dan Sejarah Umum, 1997:74). Pendidikan Kristen dalam hal ini berperan untuk mengarahkan agar setiap orang Kristen Jawa mengembangkan beberapa sikap seperti terbuka atau berani berterus terang (Mat. 5:37; Yak. 5:12), tegas terhadap dosa (I Raja 1:6; Titus 1:13), berani menyatakan sikap terhadap kebenaran sekalipun beresiko (Daniel 3, 6).

\section{Nrimo Sebagai Topeng}

Berdasarkan penelitiannya yang sangat jeli terhadap budaya Jawa, Niels Mulder mengomentari sikap orang Jawa khususnya yang masih dipengaruhi oleh tata krama 
kraton seperti Jogyakarta dan Surakarta, ialah bahwa "orang menyembunyikan diri mereka di balik topeng senyuman dan tata krama" (Pribadi dan Masyarakat Di Jawa, 1996:62). Sikap tersebut adalah bagian dari falsafah nrimo yang harus dijaga agar orang lain tetap berpendapat bahwa orang Jawa itu baik, meskipun diperlakukan dengan sewenang-wenang. Etika yang dijunjung tinggi melalui keramahtamahan serta kepandaian membawa diri dimanfaatkan untuk mengelabui agar isi hati yang sebenarnya tidak terbaca oleh orang lain. Nilai iman Kristen mengajarkan ketulusan hati melalui kejujuran hati dan tindakan (Ams.11:3). Allah tidak menghendaki kepurapuraan untuk menutupi kata hati yang sesungguhnya. Ia menghendaki kata hati selaras dengan tindakan, bukan nilai nrimo yang cenderung" di luar dan di dalam lain" (Mat. 5:37).

\section{Kesimpulan}

Falsafah Nrimo merupakan salah satu unsur dalam tatanan masyarakat Jawa yang mempengaruhi perkembangan hidup secara pribadi maupun kelompok. Penanaman sejak kecil melalui ajaran maupun percontohan dari lingkungan keluarga dan masyarakat, menghasilkan perilaku nrimo yang mempengaruhi perkembangan sepanjang hidup. Ditinjau dari segi psikologis, falsafah nrimo memberikan pengaruh positif maupun negatif bagi perkembangan setiap individu. Beberapa teori psikologi dijadikan sebagai sarana untuk mengkaji pengaruh falsafah nrimo menuju perkembangan yang sehat. Peran Pendidikan Kristen menyikapi kelekatan falsafah nrimo dalam kehidupan orang Jawa sangat berarti. Keluarga sebagai agen sosial pertama, gereja sebagai lembaga pendidikan rohani, sekolah yang merupakan sarana mendapatkan pendidikan formal serta masyarakat sebagai kesatuan komunitas, semuanya dapat bekerja sama untuk mengarahkan masyarakat Jawa bertindak bijaksana dalam menyikapi berbagai persoalan yang muncul dalam kehidupan seharihari. Bagi orang Jawa yang telah menjadi Kristen, Pendidikan Kristen sangat berarti, sehingga dapat menempatkan falsafah nrimo sejalan dengan prinsip firman Tuhan.

\section{Daftar Pustaka}

Anthony, Michael J. Christian Education: Foundations for the Twenty-first Century. Baker Academic.

Downs, Perry G. Teaching for Spiritual Growth. Zondervan Publishing House.

Gunarsa, Singgih D. Psikologi Perkembangan Anak dan Remaja. Jakarta: BPK Gunung Mulia.

Institute, AGGRA. Hangudi Luhuring Budaya Jawa. Jakarta: Asri Bintoro. 
Monks, F.J., AMP Knoers \& S.R. Hadinoto. Psikologi Perkembangan. Gadjah Mada University Press.

Mulder, Niles. Pribadi dan Masyarakat di Jawa, Jakarta: Pustaka Sinar Harapan, 1996

Rimm, Sylvia. Mendidik dan Menerapkan Disiplin pada Anak Prasekolah, Jakarta: Penerbit PT Gramedia Pustaka Utama.

Sastrosupono, M., Suprihadi. Sinkretisme Dan Orang Kristen Jawa, Bandung: Lembaga Literatur Baptis.

Susilo, Budi. Psikologi Perkembangan Perspektif Sepanjang Hayat, Salatiga: Universitas Kristen Satya Wacana.

Sidjabat, Binsen Samuel. Pendewasaan Manusia Dewasa, Bandung: Institut Alkitab Tiranus.

Tomatala, Y. Teologi Kontekstualisasi (Suatu Pengantar), Malang: Yayasan Penerbit Gandum Mas, 2001

Tim Bina Karya Guru. Sejarah Nasional dan Sejarah Umum, Surabaya: Penerbit Erlangga, 1997

Wilhoit, James C., Dettoni, John M. Nurture That Is Christian, A Bridgepoint Book.

Wahono, Wismoady, S. Pro-Eksistensi, Jakarta: BPK Gunung Mulia, 2001 